\title{
Myricetin suppresses p21-activated kinase 1 in human breast cancer MCF-7 cells through downstream signaling of the $\beta$-catenin pathway
}

\author{
$\mathrm{DE} \mathrm{JIAO}^{1}$ and XUE DONG $\mathrm{ZHANG}^{2}$ \\ Departments of ${ }^{1}$ Breast and Thyroid Hernia Surgery and ${ }^{2}$ Pathology, \\ Liaocheng People's Hospital, Liaocheng, Shandong 252000, P.R. China
}

Received December 17, 2015; Accepted January 21, 2016

DOI: $10.3892 /$ or.2016.4777

\begin{abstract}
As a main active compound in the bark of waxberry (Myrica rubra), myricetin is a macrocyclic diarylheptanoid, and can trigger the apoptosis of HeLa and PC3 cells. The aim of the present study was to elucidate the anticancer effect of myricetin on human breast cancer MCF-7 cells and to explore the possible mechanisms of action. MCF-7 cells were treated with different concentrations of myricetin $(0-80 \mu \mathrm{M})$ for 12 , 24 and $48 \mathrm{~h}$. In the present study, we found that myricetin suppressed the cell viability of the MCF-7 cells at least partly through the induction of apoptosis as determined by MTT assay and flow cytometry. Western blot analysis revealed that myricetin effectively suppressed the protein expression of p21-activated kinase 1 (PAK1), MEK and phosphorylated extracellular mitogen-activated protein kinase (ERK1/2). In addition, treatment of myricetin activated glycogen synthase kinase-3 $\beta$ (GSK3 $\beta$ ) and Bax protein expression, and inhibited $\beta$-catenin/cyclin D1/proliferating cell nuclear antigen (PCNA)/ survivin and promoted caspase-3 activity in the MCF-7 cells. These results demonstrated that myricetin suppressed the cell viability of human breast cancer MCF-7 cells through PAK1/ MEK/ERK/GSK3 $\beta / \beta$-catenin/cyclin D1/PCNA/survivin/ Bax-caspase-3 signaling.
\end{abstract}

\section{Introduction}

Breast cancer is the most common malignant cancer among females. The highest morbidity occurs in northern America and northern European countries (1). Despite the fact that China is a country with low incidence, the morbidity is increasing year by year due to changes in dietary structures, living standards and life styles (2). According to new data, the morbidity of

Correspondence to: Dr Xue Dong Zhang, Department of Pathology, Liaocheng People's Hospital, 67 Dongchang Road, Liaocheng, Shandong 252000, P.R. China

E-mail: zhongxianwen33@126.com

Key words: myricetin, human breast cancer, p21-activated kinase 1, $\beta$-catenin breast cancer is increasing yearly, and it is becoming a tumor with the highest death rates (3). Meanwhile, the age at onset is becoming increasingly younger (3).

p21-activated kinase 1 (PAK1) was first found as a member of the Pak family (4). Initially, it was cloned from cerebral tissues as p21 kinase (4). Members of the Pak family play an essential role in immune escape, motility, angiogenesis and genetic regulation (5). Therefore, the Pak family may constitute the critical node of signal transduction in the process of tumor progression. During the evolutionary process of colorectal malignant tumors, expression of Pak1 is increased. Recent studies have found that the activation of Pak1 is necessary for inducing lysophosphatidic acid and autotoxin in melanoma cells (6). In addition, Pak1 was found to be highly expressed in head and neck neoplasms (7).

As a key transmitter factor for the Wnt signal channel, $\beta$-catenin is expressed in many types of tumors (8). Its oncogenic potential in in vitro culture models and in vivo animal experiments have been extensively explored. The nuclear accumulation of $\beta$-catenin is generally considered as the symbol of $\mathrm{Wnt} / \beta$-catenin signal routine. $\beta$-catenin accumulates and enters into the nucleus, which induces the expression of target genes (9).

Waxberry is a plant of the genus Myricaceae (10). Geographically, it is distributed between 18 and $33^{\circ}$ north latitude while its economic cultivation is mainly distributed in southeast coast regions, such as Zhejiang, Jiangsu, Fujian, Guangdong and Jiangxi Provinces. Myricetin, found in the bark of waxberry, is bitter in taste and warm in property with antiviral, anti-inflammatory, antioxidant, free radical scavaging, immune adjustment, anti-androgenic and antiallergic functions (11-13). In the present study, we examined the anticancer effects of myricetin. We found that myricetin suppressed the cell viability of human breast cancer MCF-7 cells. The mechanisms involved in the effects of myricetin were also investigated.

\section{Materials and methods}

Cell culture and cell viability. Human breast cancer MCF-7 cells were maintained in RPMI-1640 medium supplemented with $10 \%$ US-qualified fetal bovine serum (FBS) (both from 
<smiles>O=c1c(O)c(-c2cc(O)c(O)c(O)c2)oc2cc(O)cc(O)c12</smiles>

Figure 1. The chemical structure of myricetin.

Invitrogen, Grand Island, NY, USA) in a humidified incubator with $5 \% \mathrm{CO}_{2}$ at $37^{\circ} \mathrm{C}$. MCF-7 cells $\left(1 \times 10^{4}\right)$ were seeded into a 96-well plate, incubated at $37^{\circ} \mathrm{C}$ and then treated with different concentrations of myricetin $(0-80 \mu \mathrm{M})$ for 12,24 and $48 \mathrm{~h}$. The medium was removed, and $50 \mu 1$ MTT $(5 \mathrm{mg} / \mathrm{ml})$ was added to each well and then incubated at $37^{\circ} \mathrm{C}$ for $4 \mathrm{~h}$. The supernatant was removed, and $200 \mu \mathrm{l}$ of dimethyl sulfoxide (DMSO; Invitrogen) was dissolved for $20 \mathrm{~min}$. Absorbance was measured at $490 \mathrm{~nm}$.

Flow cytometric analysis of the apoptotic rate. MCF-7 cells $\left(1 \times 10^{6}\right)$ were seeded into a 6 -well plate, incubated at $37^{\circ} \mathrm{C}$, and then treated with different concentrations of myricetin $(0,10$, 20 and $40 \mu \mathrm{M}$ ) for $24 \mathrm{~h}$. MCF-7 cells were washed with cold phosphate-buffered saline (PBS) twice and re-suspended in binding buffer. Subsequently, $5 \mu \mathrm{l}$ of FITC Annexin V and $1 \mu \mathrm{l}$ propidium iodide (PI) were added to the cells and incubated for $20 \mathrm{~min}$ at room temperature in the dark. The apoptotic rate was determined by flow cytometry (FACSCalibur system; BD Biosciences, San Jose, CA, USA).

Western blot analysis. MCF-7 cells $\left(1 \times 10^{6}\right)$ were seeded into a 6-well plate, incubated at $37^{\circ} \mathrm{C}$ and then treated with different concentrations of myricetin $(0,10,20$ and $40 \mu \mathrm{M})$ for $24 \mathrm{~h}$. MCF-7 cells were lysed in $100 \mu \mathrm{l}$ mammalian protein extraction reagent (M-PER; Pierce, Rockford, IL, USA) and centrifuged at 7,500 x g for $15 \mathrm{~min}$ at $4^{\circ} \mathrm{C}$. Total protein levels were determined by a BCA protein assay kit (Pierce). SDS-PAGE was performed using equivalent protein extracts $(60 \mu \mathrm{g})$ from each sample, which were then blotted onto a nitrocellulose membrane using a Mini-Protean 3 system (Bio-Rad, Hercules, CA, USA). The blots were incubated in PBS containing 5\% non-fat dry milk for $1 \mathrm{~h}$. The membranes were incubated with the primary antibodies PAK1, MEK1/2, ERK1/2, GSK3 $\beta$, $\beta$-catenin, cyclin D1, PCNA, survivin, Bax and $\beta$-actin at $4^{\circ} \mathrm{C}$ overnight. The membranes were then incubated with secondary antibody dilutions, washed with PBS containing 5\% non-fat dry milk and visualized using enhanced chemiluminescence detection reagents (ECL Advance Western Blotting Detection kit; Amersham, UK).

Enzyme-linked immunosorbent assay (ELISA). The MCF-7 cells $\left(1 \times 10^{4}\right)$ were seeded into a 96-well plate, incubated at $37^{\circ} \mathrm{C}$ and then treated with different concentrations of myricetin $(0,10,20$ and $40 \mu \mathrm{M})$ for $24 \mathrm{~h}$. The caspase- 3 assay kit (Ac-DEVD-pNA, $2 \mathrm{mM}$ ) was used to detect caspase-3 enzymatic activity in the MCF-7 cells. The absorbance was measured at $405 \mathrm{~nm}$.

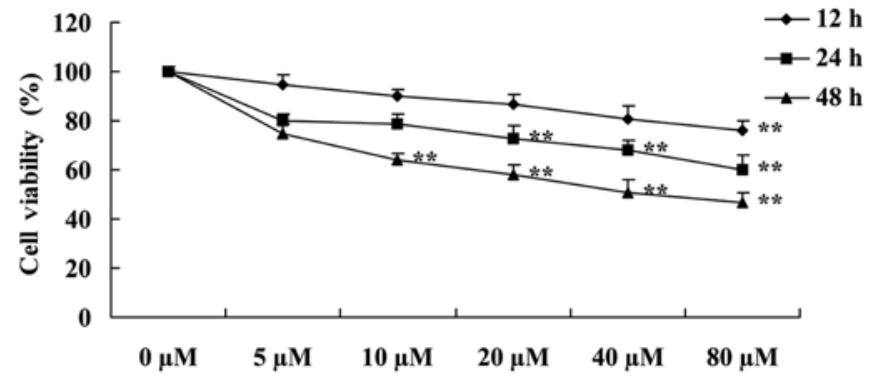

Figure 2. Myricetin suppressed the cell viability of human breast cancer MCF-7 cells. ${ }^{* *} \mathrm{p}<0.01$, compared with the control (myricetin $0 \mu \mathrm{M}$ ) group.

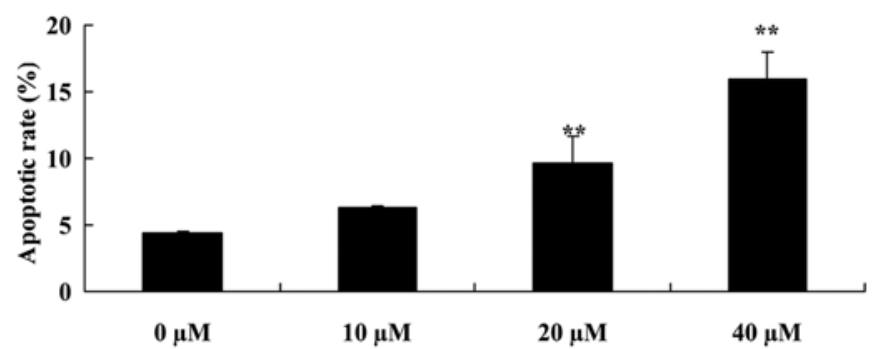

Figure 3. Myricetin induced the cell apoptosis of human breast cancer MCF-7 cells. ${ }^{* *} \mathrm{p}<0.01$, compared with the control (myricetin $0 \mu \mathrm{M}$ ) group.

Statistical analysis. Data are expressed as mean \pm standard error of the mean (SEM) and analyzed using ANOVA. The results were analyzed using a post hoc test (two-sided Dunnett's test) and one-way analysis of variance (ANOVA) to test differences between each treatment and the control. A p-value of $<0.05$ was considered to indicate a statistically significant result.

\section{Results}

Myricetin suppresses the cell viability of human breast cancer MCF-7 cells. The chemical structure of myricetin is shown in Fig. 1. MTT assay was performed to investigate the effect of myricetin on the viability of the MCF-7 cells following the treatment of myricetin. As shown in Fig. 2, myricetin suppressed the cell viability of the MCF-7 cells in a time- and dose-dependent manner. Particularly, the suppression of cell viability was evident after treatment with $80 \mu \mathrm{M}$ of myricetin for $12 \mathrm{~h}, 20-80 \mu \mathrm{M}$ of myricetin for $24 \mathrm{~h}$ and $10-80 \mu \mathrm{M}$ of myricetin for $48 \mathrm{~h}$ (Fig. 2).

Myricetin induces the cell apoptosis of human breast cancer MCF-7 cells. Similarly, we examined the effect of myricetin on the cell apoptosis of MCF-7 cells using flow cytometric analysis. We observed that compared with the controls (myricetin $0 \mu \mathrm{M}), 40$ or $80 \mu \mathrm{M}$ of myricetin significantly increased the apoptotic rate of the MCF-7 cells (Fig. 3).

Myricetin affects the PAK1 pathway in human breast cancer MCF-7 cells. In the MCF-7 models, we also examined whether myricetin affects the PAK1 pathway in MCF-7 cells. As shown in Fig. 4, myricetin ( 40 or $80 \mu \mathrm{M}$ ) significantly inhibited the 


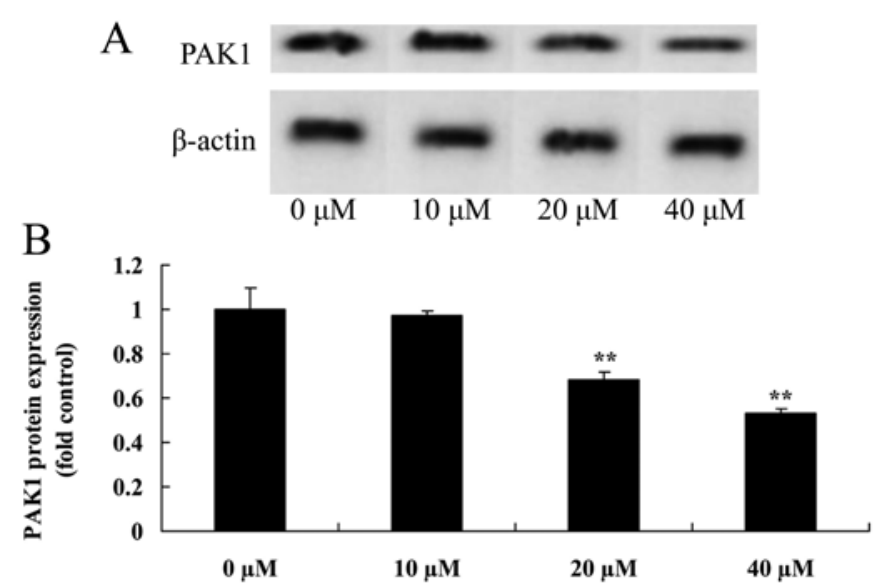

Figure 4. Myricetin affects the PAK1 pathway in human breast cancer MCF-7 cells. The anticancer effect of myricetin on (A) PAK1 protein expression and (B) statistical analysis of PAK1 protein expression in human breast cancer MCF-7 cells. ${ }^{* *} \mathrm{p}<0.01$, compared with the control (myricetin $0 \mu \mathrm{M}$ ) group.

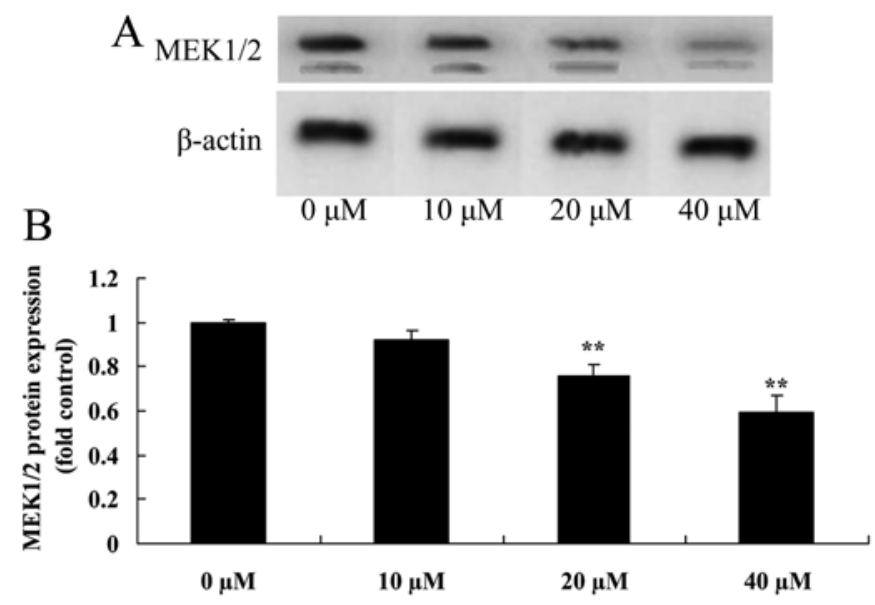

Figure 5. Myricetin affects the MEK1/2 pathway in human breast cancer MCF-7 cells. The anticancer effect of myricetin on (B) MEK1/2 protein expression and (B) statistical analysis of MEK1/2 protein expression in human breast cancer MCF-7 cells. ${ }^{* *} \mathrm{p}<0.01$, compared with the control (myricetin $0 \mu \mathrm{M})$ group.

protein expression of PAK1 in the MCF-7 cells when compared with the controls (myricetin $0 \mu \mathrm{M}$ ).

Myricetin affects the MEK1/2 pathway in human breast cancer MCF-7 cells. To ascertain whether myricetin affects the MEK1/2 pathway in MCF-7 cells, MEK1/2 protein expression was analyzed using western blot analysis. However, compared to the controls (myricetin $0 \mu \mathrm{M}$ ), treatment with 40 or $80 \mu \mathrm{M}$ of myricetin significantly suppressed the MEK1/2 protein expression in the MCF-7 cells (Fig. 5).

Myricetin affects the ERK1/2 pathway in human breast cancer MCF-7 cells. Next, the role of the ERK1/2 pathway in myricetin-induced apoptosis was determined. p-ERK1/2 protein expression was determined in the MCF-7 cells. Treatment with 40 or $80 \mu \mathrm{M}$ of myricetin significantly reduced the protein expression of p-ERK1/2 in the MCF-7 cells when compared with the controls (myricetin $0 \mu \mathrm{M}$ ) (Fig. 6).

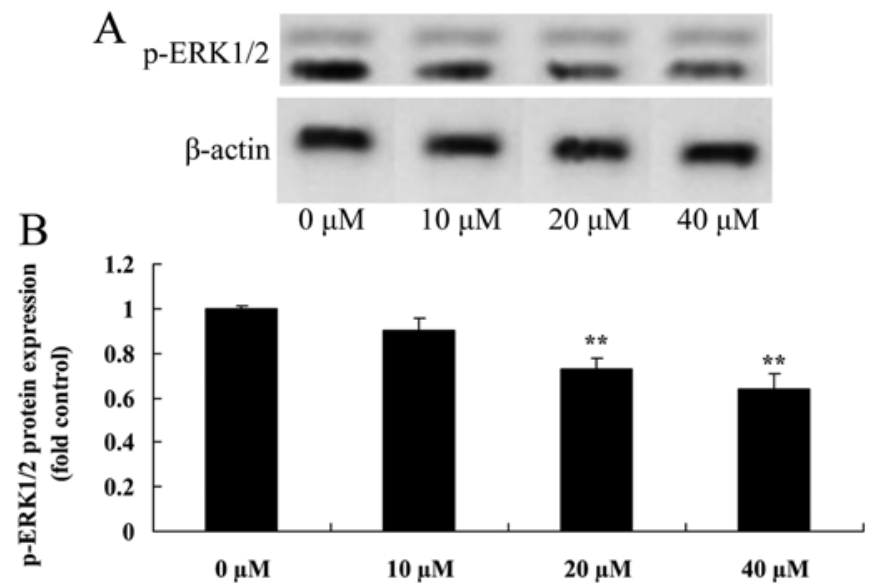

Figure 6. Myricetin affects the ERK1/2 pathway in human breast cancer MCF-7 cells. The anticancer effect of myricetin on (A) p-ERK1/2 protein expression and (B) statistical analysis of $\mathrm{p}$-ERK1/2 protein expression in human breast cancer MCF-7 cell. ${ }^{* *} \mathrm{p}<0.01$, compared with the control (myricetin $0 \mu \mathrm{M}$ ) group.

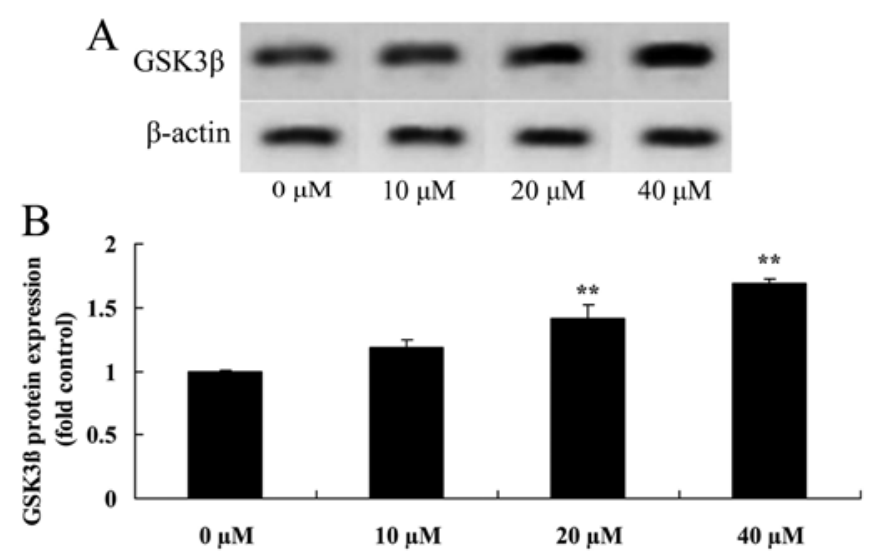

Figure 7. Myricetin affects the GSK $3 \beta$ pathway of human breast cancer MCF-7 cells. The anticancer effect of myricetin on (A) GSK3 $\beta$ protein expression and (B) statistical analysis of GSK3 $\beta$ protein expression in human breast cancer MCF-7 cells. ${ }^{* *} \mathrm{p}<0.01$, compared with the control (myricetin $0 \mu \mathrm{M})$ group.

Myricetin affects the GSK3 $\beta$ pathway in human breast cancer MCF-7 cells. GSK3 3 , a tumor-suppressor protein, was measured using western blot analysis. Compared to the controls (myricetin $0 \mu \mathrm{M}$ ), treatment with 40 or $80 \mu \mathrm{M}$ of myricetin significantly activated the protein expression of GSK $3 \beta$ in the MCF-7 cells (Fig. 7).

Myricetin affects the $\beta$-catenin pathway in human breast cancer MCF-7 cells. Western blot analysis was used to investigate the role of the $\beta$-catenin pathway on myricetin-induced apoptosis in human breast cancer MCF-7 cells. As shown in Fig. 8, treatment with 40 or $80 \mu \mathrm{M}$ of myricetin significantly suppressed the $\beta$-catenin protein expression in the MCF-7 cells when compared with the controls (myricetin $0 \mu \mathrm{M}$ ).

Myricetin affects the cyclin D1 pathway in human breast cancer MCF-7 cells. Western blot analysis was used to investigate the role of the cyclin D1 pathway in the myricetin-induced 


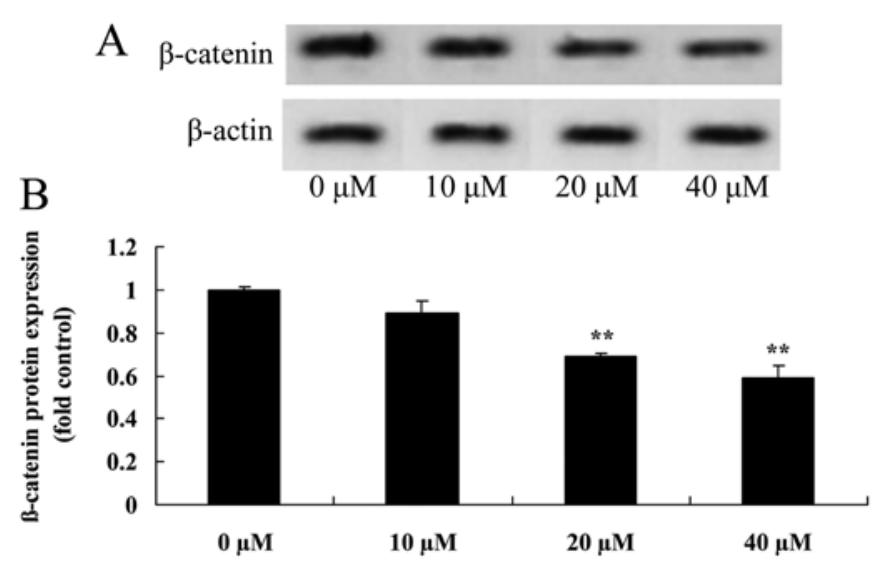

Figure 8 . Myricetin affects the $\beta$-catenin pathway in human breast cancer MCF-7 cells. The anticancer effect of myricetin on (A) $\beta$-catenin protein expression and (B) statistical analysis of $\beta$-catenin protein expression in human breast cancer MCF-7 cells. ${ }^{* *} \mathrm{p}<0.01$, compared with the control (myricetin $0 \mu \mathrm{M})$ group.

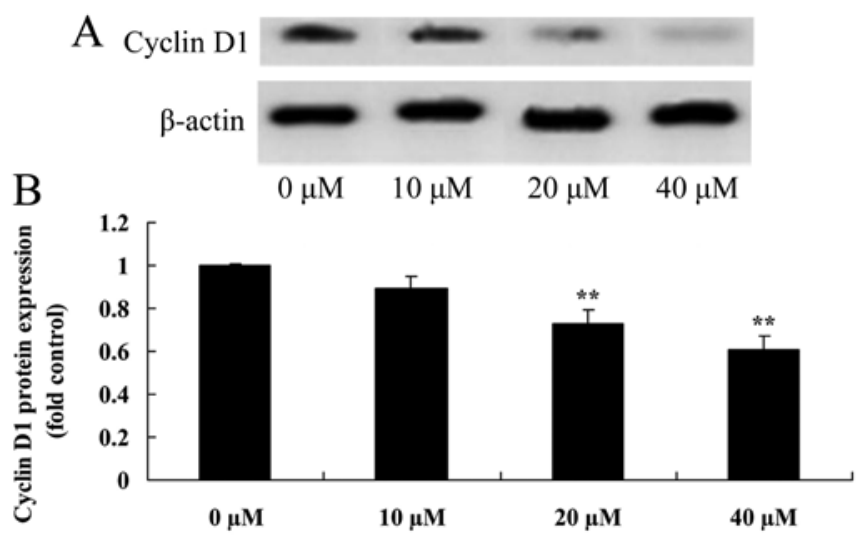

Figure 9. Myricetin affects the cyclin D1 pathway in human breast cancer MCF-7 cells. The anticancer effect of myricetin on (A) cyclin D1 protein expression and (B) statistical analysis of cyclin D1 protein expression in human breast cancer MCF-7 cells. ${ }^{* *}$ p $<0.01$ compared with the control (myricetin $0 \mu \mathrm{M}$ ) group.

apoptosis in human breast cancer MCF-7 cells. As shown in Fig. 9 treatment with 40 or $80 \mu \mathrm{M}$ of myricetin significantly inhibited the protein expression of cyclin D1 in the MCF-7 cells when compared with the controls (myricetin $0 \mu \mathrm{M}$ ).

Myricetin affects the PCNA pathway in human breast cancer MCF-7 cells. To further examine the effect of myricetin affected on the PCNA pathway of human breast cancer MCF-7 cells, PCNA protein expression in MCF-7 cells was detected using western blot analysis. As shown in Fig. 10, treatment with 40 or $80 \mu \mathrm{M}$ of myricetin significantly suppressed the PCNA protein expression in MCF-7 cells when compared with the controls (myricetin $0 \mu \mathrm{M}$ ).

Myricetin affects the survivin pathway in human breast cancer MCF-7 cells. The survivin pathway induces apoptosis in cancer cells. Thus, we aimed to ascertain whether myricetin affects the survivin pathway in human breast cancer MCF-7 cells. As shown in Fig. 11, pretreatment with 40 or $80 \mu \mathrm{M}$

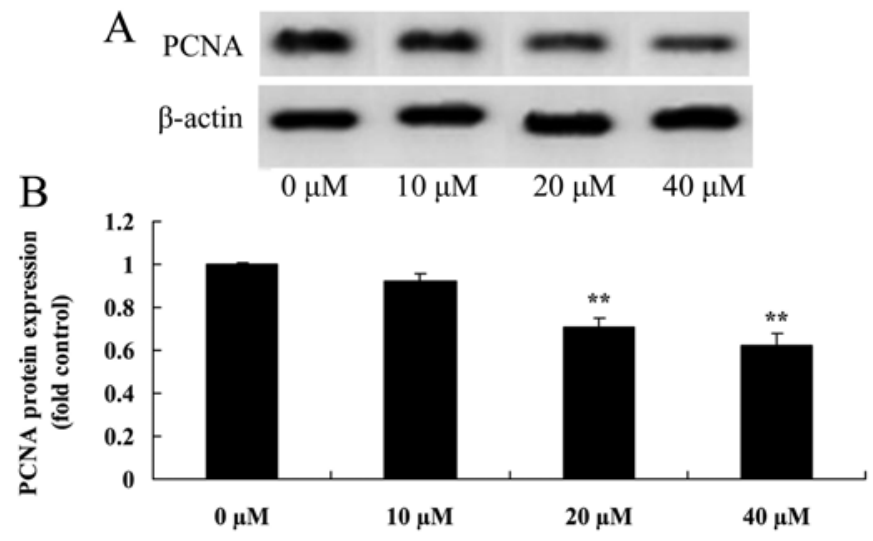

Figure 10. Myricetin affects the PCNA pathway of human breast cancer MCF-7 cells. The anticancer effect of myricetin on (A) PCNA protein expression and (B) statistical analysis of PCNA protein expression in human breast cancer MCF-7 cells. ${ }^{* *} \mathrm{p}<0.01$, compared with the control (myricetin $0 \mu \mathrm{M}$ ) group.

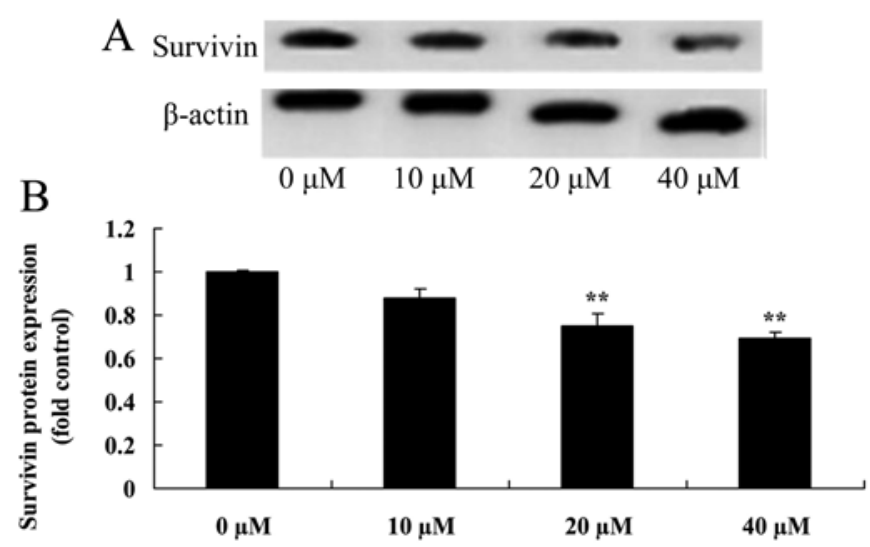

Figure 11. Myricetin affects the survivin pathway in human breast cancer MCF-7 cells. The anticancer effect of myricetin on (A) survivin protein expression and (B) statistical analysis of survivin protein expression in human breast cancer MCF-7 cells. ${ }^{* *} \mathrm{p}<0.01$, compared with the control (myricetin $0 \mu \mathrm{M}$ ) group.

of myricetin significantly inhibited the protein expression of survivin in the MCF-7 cells when compared with the controls (myricetin $0 \mu \mathrm{M}$ ).

Myricetin affects the Bax pathway in human breast cancer MCF-7 cells. To investigate whether the anticancer effect of myricetin on human breast cancer was caused by the Bax pathway, Bax protein expression of MCF-7 cells following treatment with myricetin was analyzed by western blot analysis. As shown in Fig. 12, treatment with 40 or $80 \mu \mathrm{M}$ of myricetin significantly activated the protein expression of Bax in the MCF-7 cells when compared with the controls (myricetin $0 \mu \mathrm{M})$.

Myricetin affects the caspase-3 pathway in human breast cancer MCF-7 cells. Caspase-3 assay kit was used to confirm the mechanism involved in the anticancer effects of myricetin on the apoptosis in human breast cancer MCF-7 cells. Compared to the controls (myricetin $0 \mu \mathrm{M}$ ), myricetin (40 or $80 \mu \mathrm{M}$ ) significantly increased the caspase-3 activity in the MCF-7 cells (Fig. 13). 


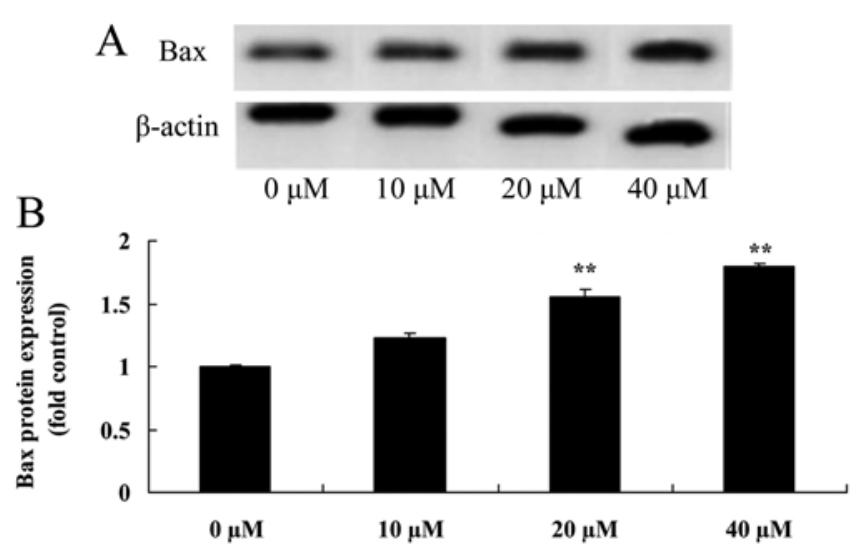

Figure 12. Myricetin affects the Bax pathway in human breast cancer MCF-7 cells. The anticancer effect of myricetin on (A) Bax protein expression and (B) statistical analysis of Bax protein expression in human breast cancer MCF-7 cells. ${ }^{* *} \mathrm{p}<0.01$, compared with the controls (myricetin $0 \mu \mathrm{M}$ ) group.

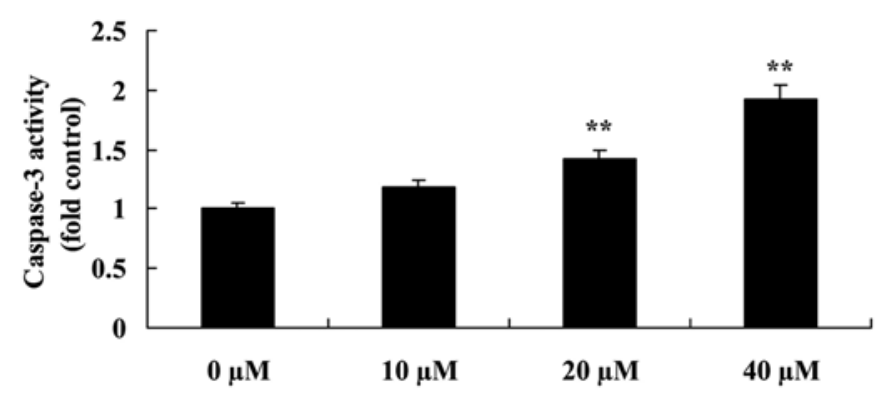

Figure 13. Myricetin affects the caspase-3 pathway in human breast cancer MCF-7 cells. ${ }^{* *} \mathrm{p}<0.01$, compared with the control (myricetin $0 \mu \mathrm{M}$ ) group.

\section{Discussion}

As one of the most common malignant cancers, the morbidity of breast cancer is increasing worldwide. In China, owing to changes in life styles and dietary structures, the morbidity of breast cancer is increasing rapidly and its age at onset is becoming increasingly younger $(2,14)$. Due to rapid progress and the wide application of molecular biology, research on the pathogenesis of cancer and its therapy has made substantial achievements (15). Our results found that myricetin suppressed the cell viability of human breast cancer MCF-7 cells at least partly through the induction of apoptosis.

Pak1 is pivotal to physiological processes such as normal cell movement, mitosis, transcription and interpretation (7). In head and neck neoplasms and sarcoma, the activities of Pak1 have been found to be higher than that in normal tissues (6). In the evolutionary process of colorectal malignant tumors, expression of Pak1 is increased (16). Studies have confirmed that Pak1 is closely associated with the invasion and metastasis of breast cancer, human oophoroma and prostate cancer, indicating the Pak1 plays an important role in normal tissue development and tumor progression $(17,18)$. Pak1 was found to be related to cellular orientation movement while motility is rather important for tumor metastasis. It has been confirmed that Pak1 has definite functions in invasion and metastasis of breast cancers induced by HER2 $(18,19)$. Further studies

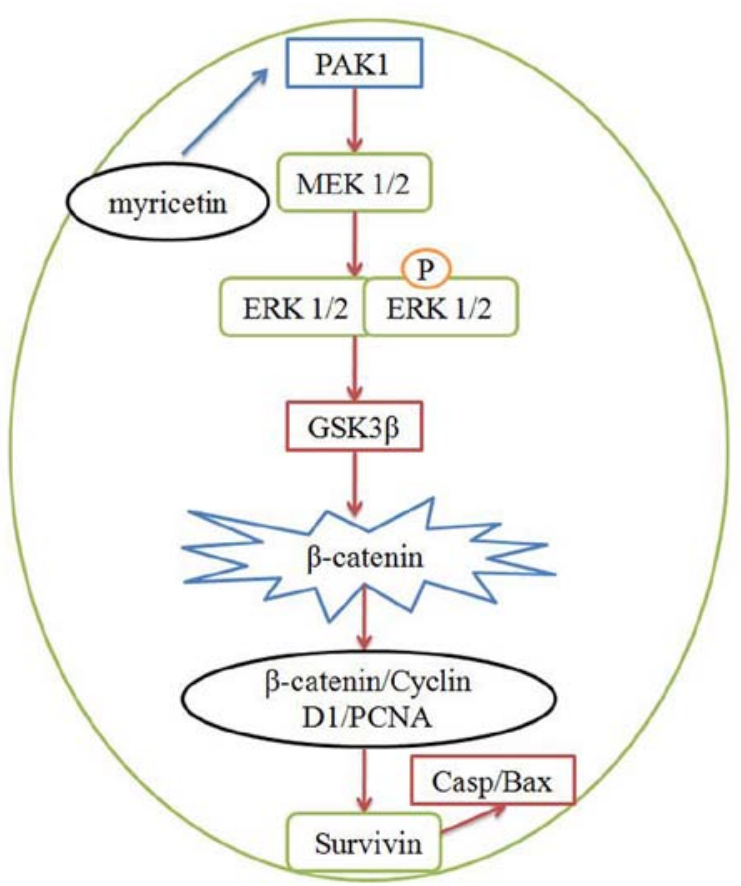

Figure 14. Myricetin suppresses p21-activated kinase 1 (PAK1) in human breast cancer MCF-7 cells through downstream signaling of the $\beta$-catenin pathway.

suggest that expression of Pak1 in breast cancer and its activities are positively related with tumor grade, and expression levels in poorly differentiated ductal carcinoma were higher than levels in higher differentiated ductal carcinoma (6). These results indicate that inhibition of the viability of MCF-7 cells following treatment with myricetin is through the PAK1 pathway. Iyer et al provide striking evidence that myricetin induces the apoptosis of hepatocellular carcinoma through inhibition of PAK1 signaling (11).

The frequency of the overexpression of MEK noted in breast cancer is $30 \%$ and is related with the poor prognosis and resistance to therapy (20). The overexpression of MEK can realize autonomous activation under conditions without extracellular ligands. This results in the occurrence of malignant tumors through the blocking of apoptosis induced by TNF (20). ERK can facilitate the proliferation of tumor cells. As an important signaling transduction pathway of MAPK, ERK can be activated by growth factors, serum, ligands of G-protein-coupled receptors and transcription factors (21). Growth factors can activate ERK through the phosphorylation of the Ras-Raf-MEK pathway. Firstly, growth factors bind with corresponding receptors on the cell surface and induce the phosphorylation of tyrosine residues on endochylema of receptors, resulting in dipolymers (22). Phosphorylated tyrosine residues can provide binding sites for proteins with $\mathrm{SH} 2$ structural domain (23). Expression of ERK in pancreatic cancer cells is significantly increased. It is known that the $\mathrm{MEK} / \mathrm{ERK}$ signaling pathway triggers the dissociation and motility of pancreatic cancer cells and improves the invasion and metastasis of pancreatic cancer cells (24). The activation of the ERK signaling pathway can regulate the migratory abilities of tumor cells and facilitate the dissemination of tumor cells. These results indicate that myricetin induced apoptosis 
in the MCF-7 cells through the MEK/ERK signaling pathway. Lim et al found that myricetin upregulated cyclooxygenase-2 expression in mouse epidermal cells through the MEK/ERK signaling pathway (25).

The Wnt signaling pathway plays a pivotal role in cell growth, progression and differentiation. Aberrant expression of the Wnt pathway is the origin of many diseases (8). In regards to the classical Wnt/ $\beta$-catenin pathway, when the Wnt signal is lost, $\beta$-catenin in the cytoplasm is at low levels, which can be degraded continuously by axin compounds (26). Axin compounds include scaffolding protein, casein kinase 1 and GSK $3 \beta$. GSK3 $\beta$ can continuously phosphorylate amino terminal of $\beta$-catenin, resulting in the degradation of $\beta$-catenin by ubiquitin (27). When cells are stimulated, Wnt signals are activated. Wnt proteins combine with FZD proteins and low density lipoprotein receptor-related protein5/6. Dsh proteins are activated. GSK3 $\beta$ is phosphorylated, which can decrease the activity of GSK3 $\beta$ (24). Axin compound cannot trigger the phosphorylation and ubiquitylation of $\beta$-catenin, resulting in the accumulation of $\beta$-catenin. It combines with $\mathrm{T}$ cell transcription factor/lymphoid enhancer binding factors and activates the expression of cyclin D1, c-myc, MMp7, CD44, Bcl-2, VEGF and survivin (28). GSK3 $\beta$ can also activate the $\beta$-catenin signaling pathway and promote the occurrence of hyperplasia of the mammary glands (28). These results indicate that GSK3 $\beta / \beta$-catenin/cyclin D1/PCNA/ survivin-associated intrinsic pathways were, at least partly, involved in the myricetin-induced apoptosis of human breast cancer MCF-7 cells. Iyer et al provide striking evidence that myricetin induces the apoptosis of hepatocellular carcinoma through inhibition of GSK3 $\beta / \beta$-catenin/cyclin D1/PCNA/ survivin signaling (11).

Bcl-2 and Bax play an essential role in cell apoptosis. The sensitivity of cells to apoptosis-stimulating factors largely depends on the ratio of bcl-2 proteins/bax proteins. The proportion of bcl-2 /bax in normal tissues is constant, which creates a balance for cell division and proliferation (29). During cell apoptosis, many proteins in the bcl-2 family play an important role in cell apoptosis. Therefore, the comprehensive expression levels of bcl-2 and bax are valuable for the occurrence, progression and prognosis of tumors (30). Our results demonstrated that myricetin inhibited the cell growth of MCF-7 cells through induction of Bax and caspase-3. Kim et al reported that myricetin induced apoptosis through the $\mathrm{Bax} / \mathrm{Bcl}-2$ dependent pathway in human colon cancer cells (10).

In conclusion, our data demonstrated that myricetin suppressed the cell viability of human breast cancer MCF-7 cells at least partly through the induction of apoptosis. Our present results revealed that the anticancer effect of myricetin on human breast cancer involved PAK1/MEK/ERK/ GSK3 $\beta / \beta$-catenin/cyclin D1/PCNA/survivin/Bax-caspase-3 signaling (Fig. 14). Thus, myricetin may be a new drug for the treatment of human breast cancer.

\section{References}

1. Kida K, Ishikawa T, Yamada A, Shimizu D, Tanabe M, Sasaki T, Ichikawa $Y$ and Endo I: A prospective feasibility study of sentinel node biopsy by modified Indigocarmine blue dye methods after neoadjuvant chemotherapy for breast cancer. Eur J Surg Oncol 41: 566-570, 2015.
2. Perez EA, Dueck AC, McCullough AE, Chen B, Geiger XJ, Jenkins RB, Lingle WL, Davidson NE, Martino S, Kaufman PA, et al: Impact of PTEN protein expression on benefit from adjuvant trastuzumab in early-stage human epidermal growth factor receptor 2-positive breast cancer in the North Central Cancer Treatment Group N9831 trial. J Clin Oncol 31: 2115-2122, 2013.

3. Tang LC, Wang BY, Sun S, Zhang J, Jia Z, Lu YH, Di GH, Shao ZM and Hu XC: Higher rate of skin rash in a phase II trial with weekly nanoparticle albumin-bound paclitaxel and cisplatin combination in Chinese breast cancer patients. BMC Cancer 13: 232, 2013.

4. Yoon JH, Mo JS, Ann EJ, Ahn JS, Jo EH, Lee HJ, Hong SH, Kim MY, Kim EG, Lee K, et al: NOTCH1 intracellular domain negatively regulates PAK1 signaling pathway through direct interaction. Biochim Biophys Acta 1863: 179-188, 2016.

5. Khare V, Dammann K, Asboth M, Krnjic A, Jambrich M and Gasche C: Overexpression of PAK1 promotes cell survival in inflammatory bowel diseases and colitis-associated cancer. Inflamm Bowel Dis 21: 287-296, 2015.

6. Nie J, Sun C, Faruque O, Ye G, Li J, Liang Q, Chang Z, Yang W, Han X and Shi Y: Synapses of amphids defective (SAD-A) kinase promotes glucose-stimulated insulin secretion through activation of p21-activated kinase (PAK1) in pancreatic $\beta$-cells. J Biol Chem 287: 26435-26444, 2012.

7. Chow HY, Jubb AM, Koch JN, Jaffer ZM, Stepanova D, Campbell DA, Duron SG, O'Farrell M, Cai KQ, Klein-Szanto AJ, et al: p21-Activated kinase 1 is required for efficient tumor formation and progression in a Ras-mediated skin cancer model. Cancer Res 72: 5966-5975, 2012.

8. Wang L, Tian H, Yuan J, Wu H, Wu J and Zhu X: CONSORT: Sam68 is directly regulated by miR-204 and promotes the self-renewal potential of breast cancer cells by activating the Wnt/beta-catenin signaling pathway. Medicine 94: e2228, 2015.

9. Dong Y, Cao B, Zhang M, Han W, Herman JG, Fuks F, Zhao Y and Guo M: Epigenetic silencing of NKD2, a major component of Wnt signaling, promotes breast cancer growth. Oncotarget 6 : 22126-22138, 2015.

10. Kim ME, Ha TK, Yoon JH and Lee JS: Myricetin induces cell death of human colon cancer cells via BAX/BCL2-dependent pathway. Anticancer Res 34: 701-706, 2014.

11. Iyer SC, Gopal A and Halagowder D: Myricetin induces apoptosis by inhibiting P21 activated kinase 1 (PAK1) signaling cascade in hepatocellular carcinoma. Mol Cell Biochem 407: 223-237, 2015.

12. Masuda T, Miura Y, Inai M and Masuda A: Enhancing effect of a cysteinyl thiol on the antioxidant activity of flavonoids and identification of the antioxidative thiol adducts of myricetin. Biosci Biotechnol Biochem 77: 1753-1758, 2013.

13. Kang KA, Wang ZH, Zhang R, Piao MJ, Kim KC, Kang SS, Kim YW, Lee J, Park D and Hyun JW: Myricetin protects cells against oxidative stress-induced apoptosis via regulation of PI3K/Akt and MAPK signaling pathways. Int J Mol Sci 11: 4348-4360, 2010.

14. Arving C, Brandberg Y, Feldman I, Johansson B and Glimelius B: Cost-utility analysis of individual psychosocial support interventions for breast cancer patients in a randomized controlled study. Psychooncology 23: 251-258, 2014.

15. Zhang J, Wang L, Wang Z, Hu X, Wang B, Cao J, Lv F, Zhen C, Zhang S and Shao Z: A phase II trial of biweekly vinorelbine and oxaliplatin in second- or third-line metastatic triple-negative breast cancer. Cancer Biol Ther 16: 225-232, 2015.

16. DeSantiago J, Bare DJ, Xiao L, Ke Y, Solaro RJ and Banach K: p21-Activated kinase1 (Pak1) is a negative regulator of NADPHoxidase 2 in ventricular myocytes. J Mol Cell Cardiol 67: 77-85, 2014.

17. McDaniel AS, Allen JD, Park SJ, Jaffer ZM, Michels EG, Burgin SJ, Chen S, Bessler WK, Hofmann C, Ingram DA, et al: Pakl regulates multiple c-kit mediated Ras-MAPK gain-infunction phenotypes in $\mathrm{Nf}^{+/-}$masT cells. Blood 112: 4646-4654, 2008.

18. Holm C, Rayala S, Jirström K, Stål O, Kumar R and Landberg G: Association between Pak1 expression and subcellular localization and tamoxifen resistance in breast cancer patients. J Natl Cancer Inst 98: 671-680, 2006.

19. Smith SD, Jaffer ZM, Chernoff J and Ridley AJ: PAK1-mediated activation of ERK1/2 regulates lamellipodial dynamics. J Cell Sci 121: 3729-3736, 2008. 
20. Dillon LM, Bean JR, Yang W, Shee K, Symonds LK, Balko JM, McDonald WH, Liu S, Gonzalez-Angulo AM, Mills GB, et al: P-REX1 creates a positive feedback loop to activate growth factor receptor, PI3K/AKT and MEK/ERK signaling in breast cancer. Oncogene 34: 3968-3976, 2015.

21. Tarkkonen K, Ruohola $\mathbf{J}$ and Härkönen P: Fibroblast growth factor 8 induced downregulation of thrombospondin 1 is mediated by the MEK/ERK and PI3K pathways in breast cancer cells. Growth Factors 28: 256-267, 2010.

22. Liu WH, Liu HB, Gao DK, Ge GQ, Zhang P, Sun SR, Wang HM and Liu SB: ABCG2 protects kidney side population cells from hypoxia/reoxygenation injury through activation of the MEK/ERK pathway. Cell Transplant 22: 1859-1868, 2013.

23. Navolanic PM, Lee JT and McCubrey JA: Docetaxel cytotoxicity is enhanced by inhibition of the Raf/MEK/ERK signal transduction pathway. Cancer Biol Ther 2: 677-678, 2003.

24. Li SQ, Wang ZH, Mi XG, Liu L and Tan Y: MiR-199a/b-3p suppresses migration and invasion of breast cancer cells by downregulating PAK4/MEK/ERK signaling pathway. IUBMB Life 67: 768-777, 2015.

25. Lim TG, Lee BK, Kwon JY, Jung SK and Lee KW: Acrylamide up-regulates cyclooxygenase-2 expression through the MEK/ ERK signaling pathway in mouse epidermal cells. Food Chem Toxicol 49: 1249-1254, 2011.
26. Zhang J, Yang Z, Li P, Bledsoe G, Chao L and Chao J: Kallistatin antagonizes Wnt/ $\beta$-catenin signaling and cancer cell motility via binding to low-density lipoprotein receptor-related protein 6 . Mol Cell Biochem 379: 295-301, 2013.

27. Chow KH, Sun RW, Lam JB, Li CK, Xu A, Ma DL, Abagyan R, Wang Y and Che CM: A gold(III) porphyrin complex with antitumor properties targets the Wnt/beta-catenin pathway. Cancer Res 70: 329-337, 2010.

28. Prasad CP, Chaurasiya SK, Axelsson L and Andersson T: WNT-5A triggers Cdc42 activation leading to an ERK1/2 dependent decrease in MMP9 activity and invasive migration of breast cancer cells. Mol Oncol 7: 870-883, 2013.

29. Zhu L, Zhu B, Yang L, Zhao X, Jiang H and Ma F: RelB regulates Bcl-xl expression and the irradiation-induced apoptosis of murine prostate cancer cells. Biomed Rep 2: 354-358, 2014.

30. Guo Y, Zhang Y, Yang X, Lu P, Yan X, Xiao F, Zhou H, Wen C, Shi M, Lu J, et al: Effects of methylglyoxal and glyoxalase I inhibition on breast Cancer cells proliferation, invasion, and apoptosis through modulation of MAPKs, MMP9, and Bcl-2. Cancer Biol Ther: 1-12, 2015. 